\title{
Time Well Spent in a Kindergarten Class: A Teacher's Reflection on Using Talk to Learn
}

\section{Laura Hope-Southcott}

Lakehead University

\begin{abstract}
Recent changes in the Ontario curricular expectations for teaching and learning have led the author to re-examine some of her teaching practices, particularly in oral language learning. In this article, the author explores what learning through talk looks like, sounds like and feels like from the kindergarten teacher's perspective. By inquiring into her own practice, drawing from the literature on classroom talk in the early years, and critically reflecting on vignettes of classroom talk as well as a teaching journal, the author as kindergarten teacher challenges her own assumptions about talk to gain a deeper understanding of its role in a kindergarten classroom. The vignettes, reflective writing and teaching journal act as signposts that map a growing understanding of talk as a tool for learning. These stories help to ground the discussion about talk in practice as well as theory, and provide insights into the challenges and opportunities of using talk for learning in kindergarten.
\end{abstract}

Key words: classroom talk, teacher research, early years, kindergarten

Laura Hope-Southcott is a student in the Joint $\mathrm{PhD}$ in Educational Studies program at Lakehead University. She is also a teacher with the Lakehead Board of Education in Thunder Bay, Ontario. Email: csouthco@ hotmail.com

Brock Education, Volume 20, No. 1, Fall, 2010, 4-18 


\section{Introduction}

I have taught kindergarten in a large school for the past six years in Northern Ontario. Recent changes in the curricular expectations in Ontario for teaching and learning have led me to reexamine some of my teaching practices, particularly in oral language learning. One of the teaching tools I use to develop the oral language skills of my students is talk.

The purpose of this article is to explore what learning through talk looks like, sounds like and feels like from one kindergarten teacher's perspective. By inquiring into my own practice (Cochran-Smith \& Lytle, 2009), drawing from the literature on classroom talk in the early years and reflecting on vignettes from my classroom, I take up my own beliefs and values of talk to gain a deeper understanding of how I use talk in my kindergarten classroom to promote learning and oral language skills. I critically reflect on the purpose of talk as well as the possibilities and challenges it presents when used as a tool for learning. A brief review of current educational reforms concerning literacy development in Ontario helps to situate talk in early years' learning while my reflections, classroom vignettes and teaching journal serve as data from my practice.

\section{Setting the Stage for Talk in Ontario}

Research shows that talk enhances learning in many ways. As students interact with each other and with the teacher, learning grows from purposeful talk: in science (Education Development Centre, 2010); in reading (Cazden, 2005; Korat, Bahar \& Snapir, 2002/2003, Paley, 1981); in writing (Ontario Ministry of Education, 2009), in oral language (Crévola \& Vineis, 2005; Heisner, 2005; Morrison \& Wlodarczyk, 2009); in drama (Paley, 1981; Cooper, 2005); in personal and social development (Bodrova \& Leong, 2003a; Heisner, 2005); and in math (Chapin, O'Connor \& Anderson, 2003; Rowan \& Jewell, 2009). Current education initiatives in Ontario emphasize the importance of early reading and writing skills. Further, reading and writing are linked intimately to the development of speaking and listening abilities or oral language skills (Kirkland \& Patterson, 2005). As Roskos, Christie and Richgels (2003) put it, "children's early reading and writing learning... is embedded in a larger developing system of oral communication. Early literacy is an emerging set of relationships between reading and writing" (p. 2). The early development of literacy skills which include reading, writing, speaking and listening, continues to be a central focus of teachers, administrators and school boards across Ontario as a means to ensure students' future academic success. "Young children need writing to help them learn about reading, they need reading to help them learn about writing; and they need oral language to help them learn about both" (Roskos, Christie \& Richgels, 2003, p. 3). Talk is recognized as an important aspect of literacy. The 2006 revised Ontario kindergarten curriculum document outlines the primary role of oral language as the "basis for literacy, thinking and socializing" (Ontario Ministry of Education, 2006, p.15) and a fundamental skill for later learning. The curriculum document states that "effective programming occurs in the context of a rich oral-language environment and contains engaging language resources that provide the foundation for successful literacy development" (p.1), establishing literacy and in particular, oral language development as a key component in early years' education. At the same time, concerns have been raised that many children are entering schools without sufficient school-based language skills (Crévola \& Vineis, 2005) which place them at a disadvantage.

Discussions about the relevance of oral language development are particularly important to kindergarten teachers for several reasons. In late 2009, the Ontario government announced a 
commitment to full-time kindergarten for 35,000 children in 2010 and 50,000 early learners by 2011 (Babbage, 2010). Recent changes in focus in early years' program to more play-based learning as well as full day everyday programs will continue to shape teachers' daily work. Early years teams will need to plan and implement a program that attends to each student's academic, social and emotional needs as well as meet the expectations set out in the curricular document. So where does talk as a tool for learning fit into an early learning program focused on play-based learning? How will kindergarten teachers plan for oral language development? Critical reflections on how 4 and 5 year olds' will spend their days at school are timely as communities, administrators, educators, and parents start to plan for and implement a full-time kindergarten program which begins for many Ontario families in the fall of 2010 in 600 provincial schools.

\section{Talk in My classroom}

Cummins suggests that children with typical language development come to school at age four or five fluent in their home language (Ontario Ministry of Education, 2007) and able to communicate their interests and needs in the language spoken at home. Hansen (2004) contends that young learners use talk to "construct language and a view of reality" (p. 115) as well as make sense of the world around them.

A visitor to my kindergarten classroom might see a group of students on the carpet reading a book together, discussing the antics of the main character. Students playing at the sand table might engage in a conversation about whether or not the dinosaur bones should be hidden under the sand or placed on top. Later in the day, we might gather in a circle to share our news or to discover what the special person of the day has brought to share. During the day, I sit down with a group of students or with an individual to have a conversation about work that we are doing, clarify a point, scaffold a learning opportunity, answer a question or share a moment together. Oral language is central to learning in my classroom and talk is the tool I use most often to encourage the oral language development of the young learners.

Is talk time well spent in kindergarten and how does it support learning? I reflect how talk can be used throughout the school day, in various subject areas and across both formal and informal learning experiences to scaffold learning.

\section{Talk as a Tool for Literacy Learning}

Opportunities for talk in kindergarten abound daily where language "is the natural outcome" of learning (Wilkinson, 1978, p. 74). The key for teachers is to value, seek out and expand on the learning that can happen through talk. My reflective writing helps me to make sense of our learning during a turn and talk activity.

Turn and talk...

"Turn to your partner, knees to knees. Tell me what you think this book is all about", I say. Most of the students are looking at the cover of the book that I have just held up, keenly eyeing the illustration of a monster smiling back at them. He is green with pink ears; his hands are folded neatly behind his back and he has a mischievous glint in his eye. Familiar with the turn and talk routine, they sit facing each other as we share our ideas with a partner and listen as our partner shares with us. They know that a good listener is quiet, waits until the speaker is finished, and thinks about what the speaker is 
saying. Then we talk about what our job is during the lesson - to make a prediction. I sit down on the carpet with a few of the partners. I want to know what they are saying and if they are being good listeners. What are their predictions? Some think it is about a monster on vacation; others suggest it is about a family of monsters. "Has everyone had time to share?" I ask and look around the room as I wonder what the other partners have talked about. Have they focused on making a prediction? Are they talking about the book? Has each partner contributed something to the conversation? I want to remember to reflect on these questions later on in my teaching journal. As I gather my thoughts, I return to the chart paper at the edge of the carpet and start to write down their predictions. (Hope-Southcott, personal reflection, winter 2008)

Chapin, O'Connor and Anderson (2003) refer to this type of classroom talk as partner talk (p. 19). Partner talk has many benefits in a kindergarten classroom. It allows students an opportunity to clarify their thinking or ask a question with a partner before sharing ideas with the whole class (Chapin, O'Connor \& Anderson, 2003). It helps children to practice or rehearse what they want to say in a safe environment. Partner talk can also be an opportunity for children to take risks and try out their thinking.

In kindergarten, establishing a routine that encourages children to use partner talk to scaffold learning can be challenging. Initially, I was concerned about the level of noise in the classroom, losing control of our book talk, regaining student focus after the activity, and uncertain about how to teach the logistics of the strategy to young learners. When I first introduced "turn and talk", some children seemed excited by the opportunity to talk to a friend. Others seemed confused by the break in our daily story time routine.

As I reflected on the type of talk that was occurring I realized that our partner talk wasn't opening up the kinds of possibilities for learning as I had hoped and that much of the talk in the room was not related to our story. The children's conversations were about a game that they had played at recess, what centre they wanted to choose later on in the morning or on what they had done the night before. Few children were using the time to make predictions about the book that we were to read. Sometimes only one partner talked. When both students were talking, I wasn't sure that partners were actively listening to each other, using the time to practice their thoughts out loud, or to build on each other's knowledge.

Not all classroom talk is purposeful and moves learning forward even though it may be enjoyable as Chapin, O'Connor and Anderson (2003) point out. Students may require the teacher's help to sift through their ideas. While the students enjoyed their conversations with each other during our first "turn and talks", their talk was not helping them to make predictions to our stories. Teachers also need to reflect on what kind of talk students need to engage in to deepen their understanding of what they are learning and how they are learning (Chapin, O'Connor \& Anderson, 2003). As a result of listening to turn and talk partners, I understood that I needed to be more explicit about what partner talk looked, sounded and felt like. It is not the amount of talk that is at issue but rather how talk can be used to move learning forward by clarifying and extending students' thinking.

Hanson (2004) believes that activities which highlight talk provide opportunities for young learners to "receive and express ideas, impressions and feelings" (p. 563). After many "turn and talk" experiences during which I modeled expectations, redirected conversations, prompted partners with sentence starters, and demonstrated how to take turns, students began to use the time for talk in a more focused way. By reflecting on what was working and what wasn't 
working during our "turn and talks", I was able to intentionally plan for and teach students how to use the time to talk to make predictions. In my classroom, turn and talks" eventually became a time for book talk that explored their ideas and connections to new learning.

\section{Engaging in Science Talk}

Gallas, Anton-Oldenburg, Ballenger, Beseler et al. (1996) contend that talk develops from many different types of classroom encounters and helps to expand upon children's understanding of the world around them (Korat, Bahar, \& Snapir, 2002/2003). The following vignette illustrates how my students explored sinking and floating through talk. I reflect on how talk scaffolds my students' understanding in science as they discuss their observations and listen to each other's thinking.

\section{Will it sink or float?}

We are all gathered around the table looking at the tub of water in the centre. Children are taking out various items that I had placed in a basket beside the tub. There is a soft bright pink feather on top. Someone has picked up the rock and remarked that it is heavy. There is a lot of talk among the students as they discuss the shape, size and texture of the gathered items. Some are talking about similar objects they have at home. Some are wondering out loud what we are going to do next. There is a cacophony of voices as we explore and learn together. "Which objects do you think will float and why do you think that?" I ask as soon as everyone has had a chance to explore what is in the basket. (Hope-Southcott, personal reflection, fall 2008)

By using whole-class discussion, my students and I were able to "share [our] thinking, explain the steps in [our] reasoning, and build on one another's contribution" during our science lesson (Chapin, O'Connor \& Anderson, 2003, p. 17). Fisher (2007) posits that "every dialogue create[s] a space of possibility for shared thinking" (p. 612) and opportunities for learning together. Everyone was engaged in their science work and the talk around the table supported students' learning.

As we examined each object and shared our thinking, someone suggested that marbles sink while another remarked that the sponge soaks up water. One student suggested that light objects would float. In addition to sharing their thinking, students were able to build on each other's ideas and to rethink what they knew to be true. The science lesson not only introduced the idea of sinking and floating, it gave us "something to talk about" (Viadero, 2010, para. 23) and grounded our classroom talk in our science learning. As the objects were finally placed in the water, the students talked about their observations. They noted which objects floated and which objects sank to the bottom of the bin of water. Sometimes, they expressed disbelief at the result and the object was placed again in the bin.

Heisner (2005) argues that "by providing opportunities for prolonged periods of social interaction, we give children the opportunity to participate in lengthy conversations with their peers, thereby helping them learn the 'give-and-take' of mature dialogue" (para.13). In science that day, classroom talk helped to scaffold learning as the students discussed the different objects and what they knew about their properties. Their prior knowledge helped them to make informed guesses about whether the objects would sink or float. Students also benefitted from listening to their peers, testing out their theories, and sharing ideas. 
Classroom talk gives students an opportunity to take up new ideas, to think out loud about concepts, to share important discoveries and interact within their classroom community (Chapin, O'Connor \& Anderson, 2003; Cooper, 2005; Cullinan, 1993). Talk also helps teachers to better understand their students' thinking and to address misconceptions or identify gaps in understanding (Chapin, O'Connor \& Anderson, 2003) as they listen closely to the talk in their classrooms.

\section{Practicing Talk through Play}

Korat, Bahar \& Snapir (2002/2003) suggest that "the idea of playing with language, oral and especially written language, during dramatic play is not nearly as common as it ideally should be" (para. 36). Dramatic play gives children another opportunity to practice and enrich their oral language skills. Heisner (2005) contends that "through the social interaction that takes place during socio-dramatic play, children develop the ability to express thoughts in a logical sequence, share ideas about events in which there is not shared context, and develop vocabulary" (para. 1). The following vignette illustrates the talk that can result from playful learning experiences in the drama centre.

\section{Mary's story...}

I find a note pushed into my hand. Mary has written, "The cow is sick. It has the mooing disease. Can you help?" We rush over to the drama centre as she explains the situation to me. We arrive at the centre to find it a hub of activity. Twenty minutes of playtime has passed and the children have turned the fire station into an animal rescue mission. They are talking excitedly as they diagnose the horse with a cold and discover the frog has a broken leg. One child is writing out a prescription on a pad of paper, another is answering emergency calls on the plastic telephone, and someone has commandeered the fabric fire truck to save more animals. There is a feeling of excited efficiency as the students talk to each other, organize the next rescue mission and negotiate joint meaning during playtime. (Hope-Southcott, personal reflection, spring 2008)

In the early weeks of May, our classroom drama centre transforms into a fire station and is soon to take on a wing for animal rescue as the children expand on their play scenario. In the drama centre, there are many tools that spark conversation, scaffold learning and guide play. Pads of paper, pencils, markers, a telephone directory, as well as books on community helpers, trucks and animals are found on the drama centre shelves. Plush animals, a doctor's bag and a fabric fire truck engage and extend students' play. As they take on their roles in the emergency, talk in the drama centre scaffolds learning.

Children make deeper connections to what they see around them as they play together. They plan, negotiate, communicate, and create meaning (Gee, 1999) through their play. One way they deepen learning during play is through talk. Connecting literacy and play is an effective way to create meaningful and genuine learning experiences (Roskos, Christie, \& Richgels, 2003). Activities at the drama centre such as looking up telephone numbers, referring to books at the centre and reading signs help to support children's early reading. As my students write out pretend prescriptions, directions or take messages during their play they reinforce early writing skills. Oral language develops as they talk to each other about new roles, create rules for the play scenario and jointly make meaning. In addition, self-regulation skills are fostered as they learn to work together. 
Bodrova and Leong (2003c) explain the relationship between talk and play.

Children use language to plan their play scenario, to negotiate and act out their roles, to explain their "pretend" behaviors to other participants, and to regulate compliance with the rules. In doing so, they often need to modify their speech (its intonation, register, and even choice of words) according to the requirements of a particular role or as they switch from talking in a pretend way to talking for real. (Bodrova \& Leong, 2003c, para. 15)

Although language may be a natural occurrence in a kindergarten room, connecting play and literacy requires teachers to be intentional and mindful as they plan learning experiences to meet students' needs. When teachers listen attentively to the talk that surrounds play, they can plan for ways to build on children's prior knowledge. In the drama centre, teachers sometimes do this by adding or removing resources. By having literacy tools such as pencils, markers or paper at the centre, children can make lists and notes. Books related to the drama centre can also be added to help extend the play scenario. Students can follow storylines as well as look for ideas or information. When resources are no longer being used, teachers can remove or replace them with other items to engage students. Planning long blocks of time for play gives children multiple opportunities for peer interaction and talk (Heisner, 2005). Asking children to explain what they mean or are doing, consider a different possibility, and expand on what they have said can help push their thinking and deepen their play as well. Direct teacher guidance to focus talk through questions and prompts can help children extend or add a new element to play.

There are several challenges to supporting classroom talk through play found in the literature. Heisner (2005) noted that at times, adult guidance hinders play as children engage more freely with their peers than when the teacher guides the activity more directly. Bodrova and Leong (2003a) caution that adults need to remain on the edges of play in order to scaffold learning without inhibiting it. On the other hand, young children may not have sufficient prior knowledge to create and extend pretend play situations without adult help. Children may continue to negotiate familiar play scenarios that do not push their thinking in new directions.

The complexity or familiarity of play impacts on the ability of young learners to use their play to develop literacy skills (Bodrova \& Leong, 2003b). As they act out a new or unfamiliar play scenario, children enrich their literacy skills. They engage in more complex conversations with their peers as they explain their thinking. Welsch (2008) explains that "the purposeful language interactions during pretend play require students to use their developing verbal skills to maintain and advance the play by speaking in character, suggesting actions, or directing other players" (p. 138). Bodrova and Leong (2003a) suggest that, for example, the use of symbolic representation of play objects helps enhance play and develop oral language skills. They may reimagine props and describe the purpose and function of the object in order for their peers to follow along. This helps them to develop their speaking and listening skills as well as adds a layer of complexity to their play.

\section{Talking about Read Alouds}

Current research demonstrates the benefit of a literacy rich environment where "varied vocabulary, read[ing] and discuss[ing] books, and engage[ing] children in intellectually stimulating conversations" (Dickenson, 2002, p. 27) occur. In fact, Morrison and Wlodarczyk (2009) contend that "reading texts aloud is the single most important activity for building the 
knowledge required for reading" (p. 111). I reflect on how using talk after a read aloud may help my students to make connections.

\section{Making connections...}

Today I've planned a read aloud using a picture book. In the story, the young boy asks his grandfather to sew him a jacket from his cherished childhood blanket. After the jacket becomes worn and tattered, the grandfather cuts it down to make a vest and so the story continues until the boy is left with only a small button made from the material of his special blanket. The button is eventually lost though the child realizes that he is left with something more precious - his memories. I am very excited about reading this book, sharing my own personal connections to the story and hearing the connections my students make. They are a talkative group who enjoy engaging each other in conversation and relating storybook events to their own experiences. There are so many connections we can make with this picture book - to grandparents, treasures, special memories, and feelings of loss. I gather everyone close to me on the carpet to tell them about the story I am going to read. I let them know that they have a job to do as I read - to think of what the story reminds them of. Afterwards we will share our connections first with our elbow partners and then later the whole class. (Hope-Southcott, personal reflection, spring 2008)

Read alouds support talk in many ways- before, during and after the story. They can scaffold understanding before the read aloud as students make predictions. During the read aloud, teachers can ask questions and prompts to check for comprehension and extend thinking. Students can make informed guesses about what will happen next and think about their connections. After the read aloud, follow up activities can help students explore their reactions to the story as well as look for alternative perspectives. Read alouds provide an opportunity for children to talk about their thinking, feelings, understanding, and connections (Hansen, 2004).

Hansen (2004) and Morrow (2005) agree that book talks after read alouds support students' efforts to learn new words and structures. Talk after read alouds also provide children with an opportunity to play with the language they hear in the story, use the same structures in their own talk, and manipulate words in rhyming. This helps young learners to "build blocks to reading and spelling" (Hansen, 2004, p. 116). It also helps them to make connections between what is written and what is spoken. Read alouds also support children's deepening understanding of the text as they talk about it. They make sense of the story in the same way that they make meaning of the world around them. They talk about what they know, see, and are learning.

\section{Time for Talk and Reflection}

Formal and informal learning opportunities give young students authentic experiences for talk (Ediger, 2000). The entry in my teacher's journal touches on some of my own assumptions about talk during a formal learning experience.

\section{Talking about a pumpkin...}

I tried a new idea for [our small group discussion] today. I decided to use an artifact...It was a pumpkin - orange, small, waxy, bumpy and hard. It fit into the palm of my hand like a bright orange ball. I found that the activity worked well in a small group. The pumpkin was something tangible for students to touch, smell, examine and listen to... I 
am finding it difficult to find ways to encourage them to use more than one word answers and to expand on their thoughts. I have tried to increase my wait time but it is difficult to sit so quietly while I see a look of uncertainty and fear begin to cloud their expressions...I find myself jumping in to rescue them before too long or turning to someone else to give them more time to think. I need to remember, however, to go back and pick up the threads of their conversation again. (Hope-Southcott, excerpt from teaching journal, October 22, 2008).

In my teaching journal, I reflect on how I use talk as well as quiet to support learning in my kindergarten classroom. Chapin, O'Connor and Anderson (2003) note that students need time to think and reflect before they talk in order to connect what they are thinking to what they want to say. Time for reflection gives children an opportunity to turn their thinking into talk. In this sense, silence can be purposeful in supporting children's need to process and reflect on their learning.

As I passed around the pumpkin for each student to hold, I noticed that the conversation became more animated and moved beyond the texture, shape and size of the pumpkin. Some children talked about how the pumpkin led them to think of Halloween, costumes and pumpkin lights. One group of students decided to weigh the pumpkin and compare it to our large classroom pumpkin. Although the start of our conversation was marked by one word answers, the talk that occurred as we held the pumpkin did help us to further our thinking by making connections and exploring other concepts such as heavy and light.

\section{Opportunities and Challenges to Talk}

According to Evans and Jones (2007), removing the barriers that stifle classroom talk involves a "reform of pedagogical practices that in the past have valued the acquiescence of children to quiet working practices" (p. 559). As teachers find ways to promote talk, they may face obstacles. Some of the challenges teachers face are finding the time for talk and creating an environment in which students are supported as they take risks in their learning. Small moments to capitalize on talk may also be missed as teachers' focus their attention and energies elsewhere. Taking the time for talk is important for oral language development of young learners and has the potential to open up possibilities for learning as the mystery box vignette illustrates.

\section{The mystery box...}

All eyes are on the red mystery box as I bring it into the circle. The box is rectangular with smooth fire engine red sides, top and bottom. There is a piece of red fabric covering one end, leaving just enough space for a small hand to wiggle its way inside. We are sitting with our legs crossed on the carpet and hands on our knees. There is an air of anticipation as the children imagine what is in the box - a dinosaur, a ball, or perhaps a crystal. A few guesses have already been made as circle time neighbours exchange ideas. We go over the rules for the activity one last time. "Look with your hands not with your eyes. You can touch it but you can't look at it", I explain. "Try to guess what is in the box...is it soft or hard....is it big or small...is it sharp or smooth," I say, "Try to make a picture of it in your head." Their foreheads are furrowed in concentration as I begin to go around the circle. (Hope-Southcott, personal reflection, spring 2008) 
I frequently use our mystery box to generate talk. It rarely fails to stimulate an interesting conversation as students make connections to what they are feeling, ask questions, practice new vocabulary, share ideas, and recount stories. The literature on classroom talk, however, points to several constraints that may direct classroom time and energy away from the use of talk during an activity like our mystery box.

Bodrova and Leong (2003a) contend that with "rising expectations and tougher academic standards, educators are more likely to pay attention to issues that seem to be more closely related to school readiness" (p. 12). Teachers may decide against spending time on talk when faced with heavy curricular expectations and focus on content-based activities rather than on building language skills (Aldridge, 2005). They may even ask themselves if time for talk is well spent. According to Gallas et al. (1996), "there is sometimes an irresistible urge to anchor children's oral language experiences in functional, goal-oriented, instructional activities" (p.611) that meet the emphasis on teaching discrete reading and writing skills at earlier grades (Baumer, Ferholt \& Lecusay, 2005; Cooper, 2005; Tafa, 2008). On the other hand, it can be argued that classroom talk supports academic content as language is the glue that binds learning together.

Chapin, O'Connor and Anderson (2003) note that in order to have productive classroom talk that scaffolds learning, students also need to feel able to take risks and be supported in their learning as they talk about their thinking. In a classroom where ideas are respectfully shared, students focus their talk on extending learning, exploring what they do and don't understand as well as considering different viewpoints. As students talk, others may listen, (re)think about what they know, and add to what is being said. When classroom talk is clear, thoughtful as well as respectful, all students have the potential to participate more fully in learning through talk (Chapin, O'Connor \& Anderson, 2003).

Even with these conditions in place, other challenges may arise. In their study of at-risk readers, Pransky and Bailey (2003) point out that differences between students' home culture and school culture may inhibit students' active participation in classroom talk. According to Pransky and Bailey (2003), "students from home cultures dissimilar to the school's are often at a distinct disadvantage, coming into classrooms with quite different understandings of school success, literacy, appropriate interaction between student and teacher and so on" (p. 373). Students may not always share the same prior experiences from which to draw on to support their participation in classroom talk. Teachers also need to be cognizant of their own cultural assumptions and mindful of how their beliefs and values are shaping learning experiences and the classroom environment. Pransky and Bailey (2003) suggest that teachers play an important role in helping students navigate through unfamiliar school expectations around talk. For example, they can explain that different points of view are welcome in a classroom discussion as well as create opportunities for all of their students to participate. Cooper (2005) contends that teachers may miss opportunities to build on and extend learning through talk by focusing their energies on other aspects of teaching and learning such as classroom management. Zigler and Bishop-Josef (2006) challenge the shift in focus to "quiet desk work" (p. 2) and drills in early years' classrooms in the United States. Chapin, O'Connor and Anderson (2003) argue that "few American classrooms display consistent or even occasional use of student talk" (p. 5). Some educators tend to equate a quiet classroom with an environment that promotes learning and a noisy classroom with unproductive and off-task behavior (Kalmar, 2008). In my own practice, I have noted that the opposite may hold true as students construct meaning through talk that develops with partner work, small group and whole-class discussion. On the other hand, silence can be purposeful when it is used as a time to reflect on learning and thinking. 


\section{Conclusion}

My own experience in my kindergarten classroom has shown me that there are many challenges to overcome as well as opportunities to explore when I use talk to scaffold my students' learning. The literature on classroom talk in the early years has been relatively silent about the various challenges that kindergarten teachers face in their daily work. What literature there is remains somewhat unchallenged. Although classroom conversations occur throughout the day, purposeful talk needs to be intentionally planned for, supported and critically reflected on by early years' teachers if it is to be used as a tool for learning.

Professional development for kindergarten teachers tends to focus on different teaching strategies that teachers can use in their classroom. There is little critical reflection about the opportunities and challenges these different teaching strategies present. My reflections on using talk as a tool for learning have deepened my own understanding of what talk looks and sounds like in my classroom as well as how it supports my students' learning. I found that when our talk was focused on our lesson, it helped my kindergarten students explore what they knew about scientific concepts such as sinking and floating, as well as, make connections and predictions. Our classroom talk also helped to scaffold learning in the drama centre. Children were able to talk about their play for extended periods of time, add new dimensions to play scenarios, and create layers of complexity in familiar play contexts.

At other times, our talk didn't support our learning. During the beginning of our turn and talk activities, the talk was often one-sided while other times, it was unrelated to our read alouds. Challenges also surfaced during our small group talk about pumpkins which elicited one word answers. Opening up the learning experience to include weighing and comparing pumpkins allowed my students to make connections, share math ideas and to turn their thinking into talk.

I find that talk has the potential to support learning throughout the school day. One way to do this is to enhance play and playful learning. Christie and Roskos (2006) suggest that play can be used as the vehicle for both instruction-based learning and learning through play. They go on to say that the use of "[t]heme-related dramatic play centers, linked conceptually to language and literacy content, allow more reading and writing, listening and talking that help establish new concepts and skills in action" (Christie \& Roskos, 2006, p. 18). Learning experiences can be planned for using playful learning as the vignettes, reflective writing, and teaching journal entry from my classroom illustrate.

Time for classroom talk is well spent in my kindergarten classroom as language supports children's learning and is a "fundamental resource in their development" (Christie, 2005, p. 32). By challenging our own assumptions about the possibilities and challenges of talk, teachers can use talk as a tool for learning to build on prior knowledge, celebrate home-based language skills as well as experiences, and provide for authentic learning opportunities. When there is time, support and resources for classroom talk, oral language development becomes not only the product of learning but part of the process as well. 


\section{References}

Aldridge, J. (2005). The importance of oral language. [Electronic version]. Childhood Education, 81(3), 177.

Babbage, M. (2010, January 11). Ontario to offer full day kindergarten to 600 schools. Globe and Mail. Retrieved January 11, 2010, from

http://www.theglobeandmail.com/news/national/ontario-to-offer-full-day-kindergartenin-600-schools/article1427283/

Baumer, S., Ferholt, B. \& Lecusay, R. (2005). Promoting narrative competence through adultchild joint pretence: Lessons from the Scandinavian educational practice of playworld. [Electronic version]. Cognitive Development, 20, 576-590.

Bodrova, E. \& Leong, D. (2003a). Chopsticks \& counting: Do play and foundational skills need to compete for the teacher's attention in an early childhood classroom? [Electronic version]. Young Children, 58, 10-17.

Bodrova, E. \& Leong, D. (2003b, October 22-25). Building language and literacy through play. [Electronic version]. Early Childhood Today.

Bodrova, E. \& Leong, D. (2003c, April). The importance of being playful. [Electronic Version]. Educational Leadership. April, 60(7), 50-53.

Cazden, C. (2005). The value of conversations for language development and reading comprehension. [Electronic version]. Literacy Teaching and Learning, 9(1), 1-6.

Chapin, S., O'Connor, C. \& Anderson, N. (2003). Classroom discussions: Using math talk to help students learn grades 1-6. Sausolito, C.A.: Math Solutions Publications.

Christie, F. (2005). Language education in the primary years. University of South Wales Press Ltd: South Wales.

Christie, J. and Roskos, K. (2006). Standards, science, and the role of play in early literacy education. In D. Singer, R.M. Golinkoff, \& K. Hirsh-Pasek (Eds.). Play=Learning: How Play Motivates and Enhances Children's Cognitive and Social-Emotional Growth. New York, NY: Oxford University Press. Retrieved January 5, 2010, from http://udel.edu/ roberta/play/contact.html

Cochran-Smith, M. \& Lytle, S. (2009). Inquiry as stance: Practitioner research for the next generation. New York and London: Teachers College Press.

Cooper, P. (2005). Literacy learning and pedagogical purpose in Vivian Paley's storytelling curriculum. [Electronic version]. Journal of Early Childhood Literacy, 5(3), 229-251. 
Crévola, C. and Vineis, M. (2005). Oral language reading and writing: Let's talk about it! Guidebook for instruction grades K-3. New York: MONDO Publishing.

Cullinan, B. (Ed.). (1993). Children's voices: Talk in the classroom. Newark, Delaware: International Reading Association.

Dickenson, D. (2002). Shifting images of developmentally appropriate practice as seen through different lenses. [Electronic version]. Educational Researcher, 31(1), 26-32.

Education Development Centre. (n.d.) Retrieved from http://www.edc.org/category/science.

Evans, R. and Jones, D. (Ed.). (2007). Perspectives on oracy - Towards a theory of practice. [Electronic version]. Early Child Development and Care, 177(6,7), 557-567.

Ediger, M. (2000). Speaking activities and reading. [Electronic version]. The Reading Improvement, 37(3), 137.

Fisher, R. (2007). Dialogic teaching: Developing thinking and metacognition through philosophical discussion. [Electronic version]. Early Child Development and Care, 177(6\&7), 615-631.

Gallas, Anton-Oldenburg, Ballenger, Beseler et al. (1996). Focus on research: Talking the talk and walking the walk: researching oral language in the classroom. [Electronic version]. Language Arts, 73 (8), 608-617.

Gee, J.P. (1999). An introduction to discourse analysis: Theory and method (2nd ed.). New York: Routledge.

Hansen, C. (2004). Teacher talk: Promoting literacy Development through response to story. [Electronic version]. Journal of Research in Childhood Education, 19(2), 115-129.

Heisner, J. (2005). Telling stories with blocks: Encouraging language in the block centre. [Electronic version]. Early Childhood Research and Practice, Fall, 7(2).

Hope-Southcott. Personal teaching journal, 2008-2009. Unpublished manuscript. Thunder Bay, $\mathrm{ON}$.

Isbell, R., Sobol, J., Lindauer, L., and Lowrance, A. (2004). The effects of storytelling and story reading on the oral language complexity and story comprehension of young children. [Electronic version]. Early Childhood Education Journal, 32(3), 157-163.

Kalmar, K. (2008). Let's give children something to talk about! Oral language and preschool literacy. [Electronic version]. Young Children, 63(1), 88-92.

Kirkland, L. and Patterson, J. (2005). Developing oral language in primary classrooms. [Electronic version]. Early Childhood Education Journal, 32(6), 391-395. 
Korat, O., Bahar, E. \& Snapir, M. (2002/2003). Socio dramatic play as an opportunity for literacy development: The teacher's role. [Electronic version]. The Reading Teacher, 56(4), 386393.

Morrison, V. and Wlodarczyk, L. (2009). Revisiting read aloud: Instructional strategies that encourage students' engagement with texts. [Electronic version]. The Reading Teacher, 63(2), 110-118.

Morrow, L. (2005). Language and literacy in preschools: Current issues and concerns. [Electronic version]. Literacy Teaching and Learning, 9(1), 7-19.

Ontario Ministry of Education. (2006). The kindergarten program. Ontario: Queens Press.

Ontario Ministry of Education. (2007, June). What Works? Research into Practice. Promoting Literacy in Multilingual Contexts (Cummins, J., Research Monograph \#5). Retrieved January 7, 2010 from Ontario Literacy and Numeracy Secretariat Online Access: http://www.edu.gov.on.ca/eng/literacynumeracy/inspire/research/Cummins.pdf

Ontario Ministry of Education. (2009, October). What Works? Research into Practice. Storytelling and Story writing: Using a different kind of pencil (Campbell, T. and Hlusek, M., Research Monograph \#20). Retrieved January 7, 2010 from The Literacy and Numeracy Secretariat Online Access:

http://www.edu.gov.on.ca/eng/literacynumeracy/inspire/research/WW_Storytelling.pdf

Paley, V. G. (1981). Walley's Stories: Conversations in the Kindergarten. Cambridge, Massachusetts and London, England: Harvard University Press.

Pransky, K. \& Bailey, F. (2003). To meet your students where they are you first have to find them. [Electronic version]. The Reading Teacher, 56(4), 370-383.

Roskos, K., Christie, F. \& Richgels, D. (2003). The essentials of early literacy instruction. [Electronic version]. National Association for the Education of Young Children. Retrieved November 21, 2010 from http://www.naeyc.org/files/yc/file/200303/Essentials.pdf

Rowan, N. and Jewell, M. (2009, June, 6-10). A big idea comes to life. ETFO Voice.

Tafa, E. (2008). Kindergarten reading and writing curricula in the European Union. [Electronic version]. Literacy, 42 (3), 162-170.

Viadero, D. (2010, January 13). Experts urge earlier start to teaching science. Education Week, Retrieved January 13, 2010, from http://www.edweek.org/ew/articles/2010/01/13/18preschool.h29.html?tkn=PTZF31Nuh1 Yz3rN5epDq\%2BOHToRC\%2BUDOYqsP7\&intc=es 
Welsch, J. (2008). Playing within \& beyond the story: Encouraging book-related pretend play. [Electronic version]. The Reading Teacher, 62(2), 138-148.

Wilkinson, A. (1978). The foundations of language: Talking and reading in young children. London: Oxford University Press.

Zeigler, E. \& Bishop-Josef, S. (2006). The cognitive child vs. the whole child: Lessons from 40 years of Head Start. In D. Singer, R.M. Golinkoff, \& K.Hirsh-Pasek (Eds.), Play=Learning: How Play Motivates and Enhances Children's Cognitive and SocialEmotional Growth. New York, NY: Oxford University Press. Retrieved January 5, 2010, from http://udel.edu/ roberta/play/contact.html. 